\title{
Transoral Thyroidectomy: Is It a Real Game Changer?
}

\author{
Kyung Tae (i) \\ Department of Otolaryngology-Head and Neck Surgery, Hanyang University College of Medicine, Seoul, Korea
}

Various remote-access thyroidectomy procedures have been developed over the past 20 years to avoid visible neck scarring. Of these approaches, the four that are most commonly used are the gasless transaxillary approach, the bilateral axillo-breast approach (BABA), the gasless postauricular facelift approach, and the transoral approach [1].

The gasless transaxillary robotic approach initially attracted considerable interest and enthusiasm and gained popularity, mainly in South Korea, while demonstrating similar surgical outcomes compared to conventional transcervical thyroidectomy. It provides a wide working space and broad surgical view of the thyroid gland, and it can be used to perform selective neck dissection. Moreover, total thyroidectomy and central neck dissection are feasible through a unilateral incision when performed by an experienced surgeon using a surgical robot [1]. However, the transaxillary approach is considered challenging technically, and its safety for complete contralateral lobectomy is doubtful due to limited visibility of the contralateral lobe. In addition, postoperative discomfort in the anterior chest area may last longer than usually expected, even up to 1.5 years [2]. These disadvantages have diminished medical interest in this procedure, especially in the Western world.

The robotic BABA enables surgeons to perform bilateral thyroid resection, while providing good postoperative cosmesis [1]. However, this approach has been performed only at a limited number of institutions and it may have the disadvantage of high surgical invasiveness related to creation of the working space. Further, the BABA requires breast incisions that might not be preferred by both doctors and patients. In addition, some patients have complained of band-like fibrotic contracture of the neck and anterior chest, which is related to the wide skin flap elevation required for creation of the working space in the BABA and transaxillary approaches [1].

The facelift (retroauricular) approach enables the performance of selective lateral neck dissection with thyroidectomy. Head and neck surgeons, who were already familiar with parotidectomy, were particularly satisfied with this approach. However, the initial enthusiasm for this approach has gradually diminished due to some limitations. The main drawbacks of the facelift approach include the very narrow working space and difficulty in approaching the contralateral thyroid lobe via a unilateral incision. Therefore, this procedure is usually applied for thyroid lobectomy. In addition, it requires a long incision at the postauricular area and occipital hairline, and postauricular scars tend to be hypertrophic compared to conventional anterior cervical incisions [3].

The transoral approach recently has gained popularity and interest, in contrast to other remote-access approaches [4-7]. It requires a smaller tissue dissection for the creation of the working space than other approaches, due to the relatively short distance from the oral vestibular incisions to the thyroid gland. Furthermore, it facilitates the performance of bilateral total thyroidectomy because of its midline access. This approach also provides an operative view in the superior to inferior direction, thereby facilitating the performance of central neck dissection. It enables scarless surgery, except for a small axillary incision if indicated. Therefore, its postoperative cosmesis is potentially superior to that of other remote-access approaches [1,4]. Moreover, its learning curve appears somewhat shorter than that of other procedures [7].

In summary, each of the four common remote-access thyroidectomy procedures has specific advantages and disadvantages. Although the debate among these alternatives is unlikely to reach a clear resolution, the transoral approach seems to be a real game changer. In recent years, it has been popularized worldwide among surgeons, even among those who do not generally trust remoteaccess surgery, owing to its superior cosmetic results and low morbidity rates. The surgical outcomes of the transoral approach are comparable to those of the conventional approach although they may include some unusual complications, such as carbon dioxide embolism, surgical site infection, mental nerve injury, skin burns, and trauma [4-8]. Recently, gasless transoral thyroidectomy using endoscopy or a surgical robot has been introduced. However, further studies are necessary to determine the role and effi-

Copyright () 2020 by Korean Society of Otorhinolaryngology-Head and Neck Surgery.

This is an open-access article distributed under the terms of the Creative Commons Attribution Non-Commercial License (https://creativecommons.org/licenses/by-nc/4.0)

which permits unrestricted non-commercial use, distribution, and reproduction in any medium, provided the original work is properly cited. 
cacy of gasless transoral thyroidectomy $[9,10]$. Despite some limitations and complications, the transoral approach can be considered as the most common practice in remote-access thyroidectomy. Furthermore, it is expected to be further refined and advanced concomitantly with the progression of surgical techniques, as well as with the evolution of surgical robots and more convenient endoscopic instruments in the future.

\section{CONFLICT OF INTEREST}

No potential conflict of interest relevant to this article was reported.

\section{ORCID}

Kyung Tae https://orcid.org/0000-0002-0382-2072

\section{REFERENCES}

1. Tae K, Ji YB, Song CM, Ryu J. Robotic and endoscopic thyroid surgery: evolution and advances. Clin Exp Otorhinolaryngol. 2019; 12(1):1-11.

2. Song CM, Ji YB, Bang HS, Park CW, Kim H, Tae K. Long-term sensory disturbance and discomfort after robotic thyroidectomy. World J Surg. 2014;38(7):1743-8.
3. Lee DW, Ko SH, Song CM, Ji YB, Kim JK, Tae K. Comparison of postoperative cosmesis in transaxillary, postauricular facelift, and conventional transcervical thyroidectomy. Surg Endosc. 2019 Sep 12 [Epub]. https://doi.org/10.1007/s00464-019-07113-1.

4. Tae K, Ji YB, Song CM, Park JS, Park JH, Kim DS. Safety and efficacy of transoral robotic and endoscopic thyroidectomy: the first 100 cases. Head Neck. 2020 Feb;42(2):321-9.

5. Anuwong A, Ketwong K, Jitpratoom P, Sasanakietkul T, Duh QY. Safety and outcomes of the transoral endoscopic hyroidectomy vestibular approach. JAMA Surg. 2018 Jan;153(1):21-7.

6. Kim HK, ChaiYJ, Dionigi G, Berber E,Tufano RP, Kim HY.Transoral robotic thyroidectomy for papillary thyroid carcinoma: perioperative outcomes of 100 consecutive patients. World J Surg. 2019 Apr;43(4): 1038-46.

7. Razavi CR, Vasiliou E,Tufano RP, Russell JO. Learning curve for transoral endoscopic thyroid lobectomy. Otolaryngol Head Neck Surg. 2018 Oct;159(4):625-9.

8. Kim KN, Lee DW, Kim JY, Han KH,Tae K. Carbon dioxide embolism during transoral robotic thyroidectomy: a case report. Head Neck. 2018 Mar;40(3):E25-8.

9. Park JO, Park YJ, Kim MR, Sun DI, Kim MS, Koh YW. Gasless transoral endoscopic thyroidectomy vestibular approach (gasless TOETVA). Surg Endosc. 2019 Sep;33(9):3034-9.

10. Tae K.Transoral robotic thyroidectomy using the da Vinci single-port surgical system. Gland Surg. 2020 Mar 10 [Epub]. https://dx.doi. org/ 10.21037/gs.2020.03.37. 